UDC 541.64:546.22

Author: MAZITOVA Aliya Karamovna, Doctor of Chemistry, Professor, Head of the Department «Applied and Natural Sciences»; Ufa State Petroleum Technological University; Mendeleev St., 195, Ufa, Bashkortostan Republic, Russia, 450080; elenaasf@yandex.ru;

Author: AMINOVA Guliya Karamovna, Doctor of Engineering; Ufa State Petroleum Technological University; Mendeleev St., 195, Ufa, Bashkortostan Republic, Russia, 450080; aminovagk@inbox.ru;

Author: MASKOVA Albina Rafitovna, PhD in Engineering; Ufa State Petroleum Technological University; Mendeleev St., 195, Ufa, Bashkortostan Republic, Russia, 450080; asunasf@mail.ru;

Author: YAGAFAROVA Guzel Gabdullovna, Doctor of Engineering, Professor, Head of the department «Applied Ecology»; Ufa State Petroleum Technological University, Kosmonavtov St., 1, Ufa, Bashkortostan Republic, Russia, 450062; Kafedra_ecologia@mail.ru;

Author: MAZITOV Ruslan Midhatovich, PhD in Engineering, Associate Professor; Ufa State Petroleum Technological University, Kosmonavtov St., 1, Ufa, Bashkortostan Republic, Russia, 450062; mazitovps@mail.ru

\title{
NEW PLASTICIZERS FOR PVC-COMPOSITIONS IN CONSTRUCTION
}

\section{ExTENDED Abstract:}

The work is devoted to the analysis and development of effective types of plasticizers for a wide range of finishing (linoleum) and insulating building materials (insulation tape, cable plastic) with improved mechanical and technical characteristics. In connection with the growth of consumption of finishing and insulating materials, the development of new formulations of PVC compositions for construction with the use of new plasticizers is not only an urgent task, but also within the framework of construction it allows solving the problems of effective quality control of a finished PVC composition.

This paper presents the results of the tests of octylphenoxyethylphtalates as a new chemical additivies for plasticizing PVC in the formulation of the upper and middle layers of linoleum, adhesive film and cable compound 0-40 rec. OM-40 (black). It is noted, that obtained samples of adhesive tape with their main characteristics (tensile strength at break, extension coefficient, shatter point, thermostability) correspond to technical specification (TS) 2245-001-002033122003. Obtained samples of plasticate were analyzed according to GOST 5960-72 rev. 1-9 (PVC plasticate for isolation and protective covers of wires and cables), by main characteristics (specific insulation resistance, tensile strength at break, breaking elongation, shatter point) are not inferior to commercial prototypes, and such characteristics as "Weight loss at $160^{\circ} \mathrm{C}$ » and "Water absorption" are 
significantly lower. It is noted that, in case of using octylphenoxyethyl phtalates, obtained samples of films of upper and middle layers of linoleum analyzed according to norms of STI 00203312-100-2006 have a higher melt flow rate. In addition, films obtained through introduction of suggested plasticizers possess a low value of extractability by gasoline and oils.

Keywords: benzene resistance, water absorption, PVC adhesive tape, oil resistance, materials for wire and cable isolation, octylphenoxyethyl phthalates, polyvinylchloride plasticizers, linoleum layer, Shore hardness, thermostability.

DOI: dx.doi.org/10.15828/2075-8545-2017-9-4-48-63

MACHine-REAdAble information on CC-LiCEnses (HTML-CODE) IN METAdATA OF THE PAPER

$<$ a rel="license" href="http://creativecommons.org/licenses/by $/ 4.0 / "><$ img alt="Creative Commons License" style="borderwidth:0" src="https://i.creativecommons.org/l/by/4.0/88x31.png" $/></ \mathrm{a}><$ br $/><$ span xmlns:dct="http://purl.org/dc/ terms/" href="http://purl.org/dc/dcmitype/Text" property="dct:title" rel="dct:type" $>$ New plasticizers for PVC-compositions in construction. $</$ span $>$ by $<$ a xmlns:cc="http://creativecommons.org/ns\#" href="Nanotehnologii v stroitel'stve =Nanotechnologies in Construction. 2017, Vol. 9, no. 4, pp. 48-63. DOI: dx.doi.org/10.15828/2075-8545-2017-9-4-48-63." property="cc:attributionName" rel="cc:attributionURL">Mazitova A.K., Aminova G.K., Maskova A.R., Yagafarova G.G., Mazitov R.M. $</ \mathrm{a}>$ is licensed under a $<$ a rel="license" href="http://creativecommons.org/licenses/by/4.0/" $>$ Creative Commons Attribution 4.0 International License $</ \mathrm{a}>$. $<\mathrm{br} />$ Based on a work at $<$ a xmlns:dct="http://purl.org/dc/terms/" href=" http://nanobuild.ru/en_EN/nanobuild-4-2017/" rel="dct:source" $>$ http://nanobuild.ru/en_EN/nanobuild-4-2017/</ $\mathrm{a}>$. $<\mathrm{br} />$ Permissions beyond the scope of this license may be available at $<\mathrm{a}$ xmlns:cc="http://creativecommons.org $/ \mathrm{ns} \# "$ href="elenaasf@yandex.ru" rel="cc:morePermissions">elenaasf@yandex.ru</a> .

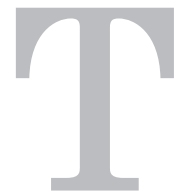

he use of plasticizers in the preparation of polyvinylchloride (PVC) compounds are caused by special characteristics of polymer's chemical structure - low elasticity, wide temperature range of plastic deformation, reduced freezing resistance. For this reason intensification of manufacturing process, expansion of the field of application PVC and providing a wide variety of its properties are connected mostly with successful solution of the problem of effective plasticizers creation [1-5].

Esters of phthalic acid are most consumed plasticizers. Phthalates are well combined with polymers and provide polymers with high physical and mechanical properties: abrasive resistance, low temperature resistance, thermostability, light resistance [1, 2, 6-10]. 
In this regard, it is not surprising that the task to explore the possibilities to develop the range of plasticizers based on phthalic acid esters are still of great interest among the researchers at the present time.

Currently di(2-ethylhexyl)phthalate (dioctyl phthalate, (DOP)) remains an international standard of PVC plasticizer. Specifications to other plasticizers are coordinated with specification for DOP. Leading position of dioctyl phthalate to this day is determined, above all, by the development of production of flexible PVC - the largest consumer of DOP [1, 2, 7, $9,10]$. Although recently the structure of PVC's consumption has changed to the direction of hard manufactures, however, plasticized materials on the base of PVC remain actual in the different fields.

Apart from the main plasticizer DOP also the most widely used ester plasticizers include dibutyl phthalate (DBP), diisononyl phthalate (DINP), diisodecyl phthalate (DIDP). However, the wide-scale and most accessible DBF does not provide the long-term exploitation of PVC-compositions. Dibutyl phthalate is high volatile that leads to intensive loss of plasticizer from plasticate, deterioration of physical and mechanical properties and reducing of lifetime of goods made of it. Despite of good low temperature properties at much lower volatility, DINP possesses lower plasticizing capability in comparison with DOP. As distinct from many plasticizers DIDP gives stability at high temperature to finished products, it is resistant to influence of different extractants and has a high heat-resistance, but to achieveme the same plasticizing effect and to save other properties of PVC-compositions it is required to introduce to $6 \%$ more than DOP. In addition, although diisodecyl phthalate has a more low volatility it is less effective than dioctyl phthalate. It should also be noted that DINP and DIDP are produced in a small scale in our country. The existing deficit of isononyl and isodecyl alcohol (they are not produced by Russian enterprises) impedes the establishment of large-scale production of plasticizers [1, 2, 10,11].

Recently, the fields of application of plasticized PVC in general and market of plasticizers in particular are under strict control of directives of environment and human health. Regulations are realized by European Council for Plasticizers and Intermediates. According to the regulations of European Union of Chemicals REACH No 1907/2006 (Registration, Evaluation and Authorization of Chemicals), manufacturers of plasticizers and products with using plasticizers must provide appropriate cer- 
tificates and in case if they are absent, production and sale of these products are prohibited in Europe. The most debating is the question about safety of DOP. According to the expert investigation carried by European scientists, PVC products which are plasticized by DOP were harmful for health. That resulted to ban of production and sale some of products in Europe [11-18].

In relation with before mentioned proportion of DOP consumption tends to decrease gradually. Although the replacement of DOP by other plasticizers is not always possible, as it leads to increase of product cost in addition such properties of product as flexibility and transparency are not always achieved, however increasing requirements make manufacturers of plasticizers to devote funds to the search and development of other safe plasticizers for PVC compounds.

In addition, the important part of the problem of creating the PVCcompounds with resistance to aggressive environments is the development of special plasticizers that satisfy modern strict requirements.

For this reason, the development of competitive formulations of PVC compounds meeting the modern ecological, technological and operational requirements with specific properties is relevant and practically important task.

We carry out investigations on development of new plasticizers [1932]. In this paper the results of the tests of octylphenoxyethyl phthalates (OPOEP) in the formulation of PVC-films of the upper and intermediate layers of linoleum, PVC adhesive tape and cable PVC-compound brand 0-40 rec. OM-40 (black) are presented.

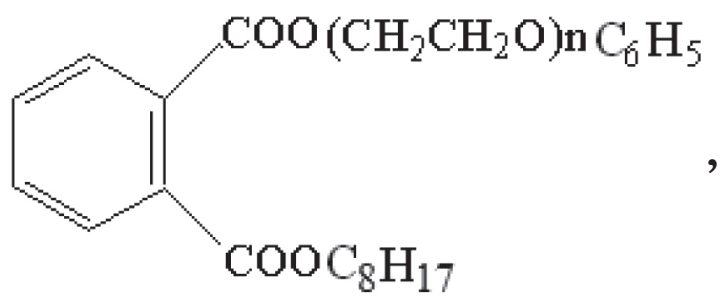

where $n=1,0-2,4$.

Suggested synthesized esters as plasticizers of PVC with third class of hazard were prepared by esterification of phthalic anhydride with oxyethylated alcohol by our previously developed methods [19, 22, 23, 25, 31]. The mass content of base substance is $99,0 \%$. 
To determine the efficiency of developed plasticizers the changing of Shor A hardness from the concentration of plasticizer were studied (plasticizer:PVC - 1:100). Based on the calculation of quantitative substitution factor (SF), which determine the required quantity of octylphenoxyethyl phtalates in comparison with DOF and which provide a necessary hardness of flexible PVC at room temperature, it was found that experimental prototype I (oxyethylation degree 1,0) is similar to DOP by plasticization efficiency. Selected OPOEP was tested in some of the PVCcompounds of building purpose. Experimental prototype I was introduced instead of commercial analogue - DOP in PVC-formulation. PVC - films of upper and middle layers of linoleum were analyzed according to requirements of СТП 00203312-100-2006. The obtained samples of PVC adhesive tape were analyzed according to TS 2245-001-00203312-2003 (PVC adhesive tape). The obtained samples of cable compounds brand O-40 rec. OM-40

Table 1

\section{The results of tests of experimental films in the industrial composition of upper layer of linoleum}

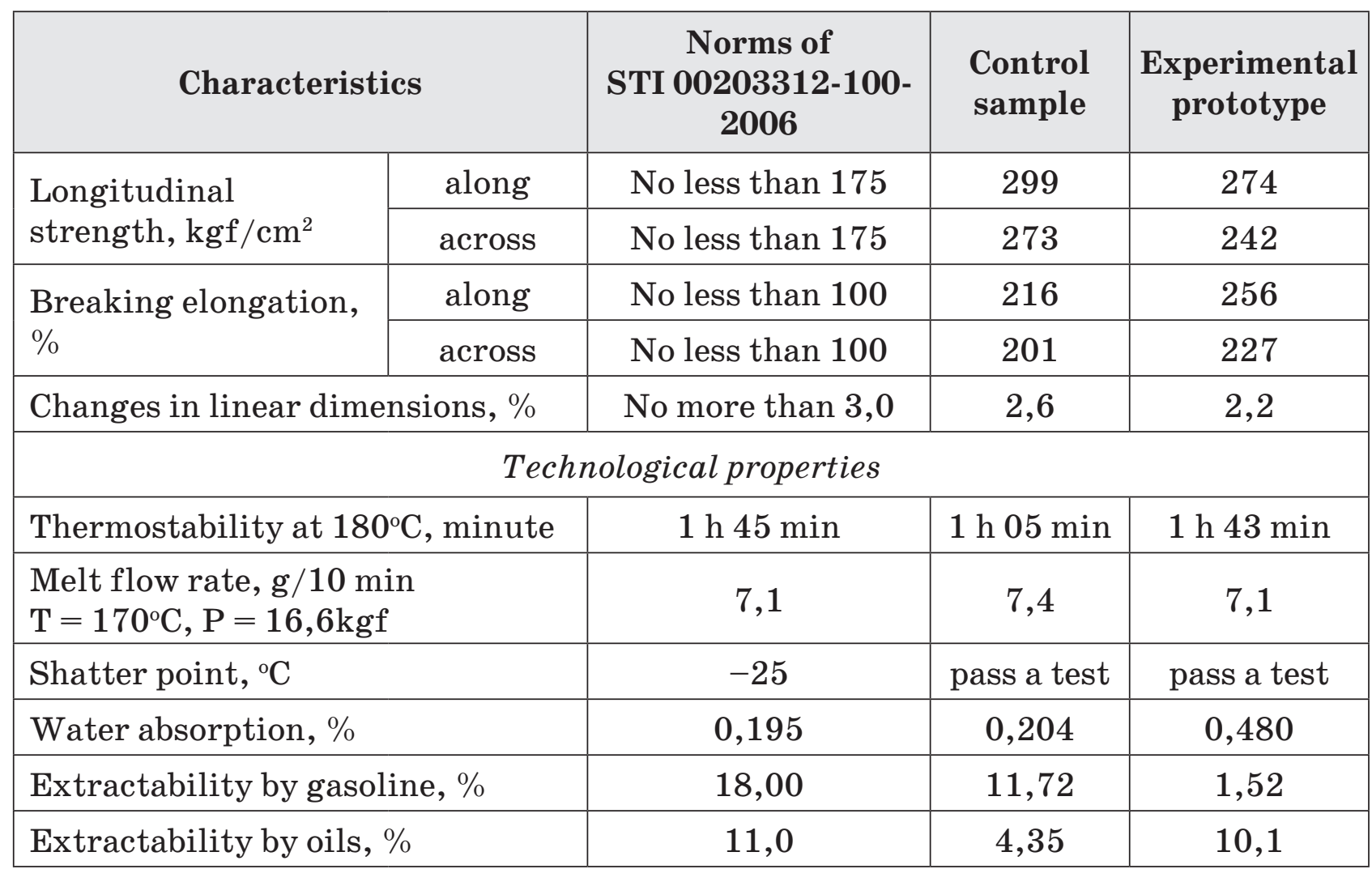


Table 2

The results of tests of experimental films in the industrial composition of middle layer of linoleum

\begin{tabular}{|c|c|c|c|c|}
\hline \multicolumn{2}{|c|}{ Characteristics } & $\begin{array}{c}\text { Norms of } \\
\text { STI 00203312-100- }\end{array}$ & $\begin{array}{l}\text { Control } \\
\text { sample }\end{array}$ & $\begin{array}{c}\text { Experimental } \\
\text { prototype }\end{array}$ \\
\hline \multirow{2}{*}{$\begin{array}{l}\text { Longitudinal } \\
\text { strength, } \mathrm{kgf} / \mathrm{cm}^{2}\end{array}$} & along & No less than 100 & 179 & 176 \\
\hline & across & No less than 100 & 159 & 137 \\
\hline \multirow{2}{*}{$\begin{array}{l}\text { Breaking elongation, } \\
\%\end{array}$} & along & No less than 100 & 251 & 248 \\
\hline & across & No less than 100 & 249 & 236 \\
\hline \multicolumn{2}{|c|}{ Changes in linear dimensions, $\%$} & No more than 3,0 & 2,6 & 2,4 \\
\hline \multicolumn{5}{|c|}{ Technological properties } \\
\hline \multicolumn{2}{|c|}{ Thermostability at $180^{\circ} \mathrm{C}, \min$} & $37 \min$ & $1 \mathrm{~h} 05 \mathrm{~min}$ & $1 \mathrm{~h} 55 \mathrm{~min}$ \\
\hline \multicolumn{2}{|c|}{$\begin{array}{l}\text { Melt flow rate, } \mathrm{g} / 10 \mathrm{~min} \\
\mathrm{~T}=170^{\circ} \mathrm{C}, \mathrm{P}=16,6 \mathrm{kgf}\end{array}$} & 9,9 & 10,0 & 9,9 \\
\hline \multicolumn{2}{|l|}{ Shatter point, ${ }^{\circ} \mathrm{C}$} & -25 & pass a test & pass a test \\
\hline \multicolumn{2}{|l|}{ Water absorption, \% } & 0,195 & 0,204 & 0,456 \\
\hline \multicolumn{2}{|c|}{ Extractability by gasoline, $\%$} & 18,00 & 11,72 & 1,52 \\
\hline \multicolumn{2}{|c|}{ Extractability by oils, \% } & 11,0 & 4,35 & 10,8 \\
\hline
\end{tabular}

(black) were analyzed according to GOST 5960-72 rev. 1-9 (PVC plasticate for isolation and protective covers of wires and cables). The results of tests are presented in the tables $1-4$.

Pictures obtained by scanning electron microscope demonstrate the resistance of linoleum on the base octylphenoxyethyl phthalates to aggressive environments in comparison with commercial plasticizer DOP.

From tests results it is evident that plasticates obtained with introducing octylphenoxyethyl phthalate in the formulation correspond to requirements of GOST and TS by all characteristics, such characteristics as resistance to oil and petroleum are better than in the experimental prototypes.

Thus, as a result of carried research we can say that octylphenoxyethyl phthalates suggested in quality plasticizers can be successfully used in PVC-compositions and have perspective of industrial application. 


\section{The results of tests of PVC adhesive tape}

\begin{tabular}{|l|c|c|c|}
\hline \multicolumn{1}{|c|}{ Characteristics } & $\begin{array}{c}\text { Norms of TS 2245-001- } \\
\text { 00203312-2003 }\end{array}$ & $\begin{array}{c}\text { Control } \\
\text { sample }\end{array}$ & $\begin{array}{c}\text { Experimental } \\
\text { prototype }\end{array}$ \\
\hline Visual appearance of tape & $\begin{array}{c}\text { The tape must not have } \\
\text { defects such as inclusions, } \\
\text { through holes, breaks }\end{array}$ & Without defects & Without defects \\
\hline Tensile strength at break, N/cm & No less than 50 & 73 & 72 \\
\hline Extension coefficient, $\%$ & No less than 80 & 277 & 277 \\
\hline Shatter point, ${ }^{\circ} \mathrm{C}$ & Not above -30 & pass a test & pass a test \\
\hline \multicolumn{3}{|c|}{ Technological properties } \\
\hline Thermostability at $180^{\circ} \mathrm{C}, \mathrm{min}$ & GOST $14041-91$ & $2 \mathrm{~h} 37$ min & $2 \mathrm{~h} 29$ min \\
\hline $\begin{array}{l}\text { Melt flow rate, at } \mathrm{T}=180^{\circ} \mathrm{C}, \mathrm{H}= \\
16,6 \text { kgf, } \mathrm{g} / 10 \mathrm{~min}\end{array}$ & GOST $11645-73$ & 10,5 & 13,9 \\
\hline
\end{tabular}

\section{The results of tests of $\mathrm{PVC}$ adhesive tape brand 0-40 рец. OM-40 (black)}

\begin{tabular}{|c|c|c|c|}
\hline Characteristics & $\begin{array}{l}\text { Norms of GOST } 5960-72 \\
\text { rev. 1-9 (1 quality) }\end{array}$ & $\begin{array}{l}\text { Control } \\
\text { sample }\end{array}$ & $\begin{array}{l}\text { Experimental } \\
\text { prototype }\end{array}$ \\
\hline $\begin{array}{l}\text { Specific insulation resistance at } \\
20^{\circ} \mathrm{C}, \mathrm{Ohm} \cdot \mathrm{cm}\end{array}$ & No less than $1 \cdot 1010$ & $9,0 \cdot 1012$ & $6,2 \cdot 1012$ \\
\hline $\begin{array}{l}\text { Tensile strength at break, kgf/ } \\
\mathrm{cm}^{2}\end{array}$ & No less than 110 & 147 & 142 \\
\hline Breaking elongation, $\%$ & No less than 280 & 385 & 278 \\
\hline Shatter point, ${ }^{\circ} \mathrm{C}$ & Not above -40 & выдерживает & выдерживает \\
\hline $\begin{array}{l}\text { Weight loss at } 160^{\circ} \mathrm{C} \text {, within } 6 \mathrm{~h} \text {, } \\
\%\end{array}$ & No more than 3,0 & 2,2 & 1,7 \\
\hline $\begin{array}{l}\text { Hardness, } \mathrm{kgf} / \mathrm{cm}^{2}, \\
\text { at } 20^{\circ} \mathrm{C} \\
\text { at } 70^{\circ} \mathrm{C}\end{array}$ & $\begin{array}{l}\text { No less than } 9-20 \\
6-12\end{array}$ & $\begin{array}{c}12,5 \\
7,3\end{array}$ & $\begin{array}{c}11,9 \\
7,4\end{array}$ \\
\hline Water absorption, $\%$ & No more than 0,45 & 0,080 & 0,052 \\
\hline Softening point, ${ }^{\circ} \mathrm{C}$ & $170 \pm 10$ & 171 & 171 \\
\hline Density, $\mathrm{g} / \mathrm{cm}^{3}$ & No more than 1,4 & 1,38 & 1,38 \\
\hline \multicolumn{4}{|c|}{ Technological properties } \\
\hline Thermostability at $180^{\circ} \mathrm{C}, \mathrm{h}$ & GOST 14041-91 & $3 \mathrm{~h} 15 \mathrm{~min}$ & $3 \mathrm{~h} 13 \mathrm{~min}$ \\
\hline $\begin{array}{l}\text { Melt flow rate, } \mathrm{g} / 10 \mathrm{~min} \text { at } 190^{\circ} \mathrm{C} \\
\mathrm{P}=10 \mathrm{kgf} / \mathrm{cm}^{2}\end{array}$ & GOST 11645-73 & 103,3 & 102,6 \\
\hline
\end{tabular}



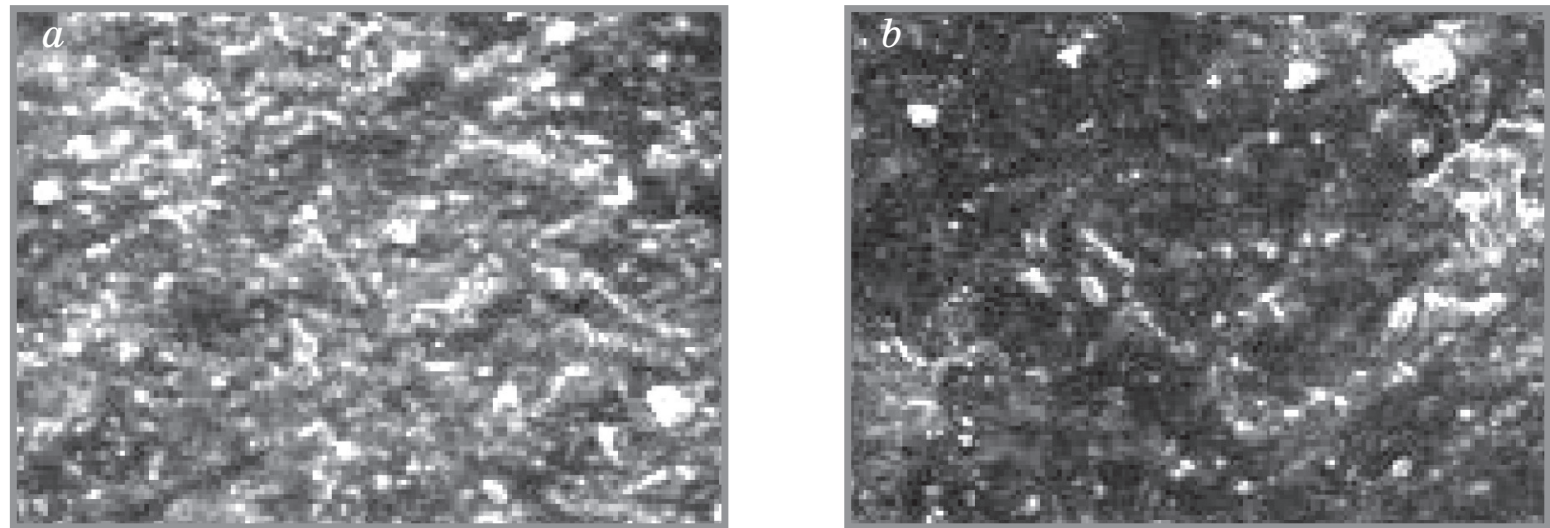

Fig. Optical micrographs of samples of the upper layer of linoleum with octylphenoxyethyl phthalate (a) and DOP (b) (resolution 500)

\section{References:}

1. Tinius K. Plastifikatory [Plasticizers]. Moscow, Himija [Chemistry], 1964. 915 p. (In Russian).

2. Burstein R.S., Kirillovich.V.I., Nosovskii Yu.E. Plastifikatory dlja polimerov [Plasticizers for polymers]. Moscow, Himija [Chemistry], 1982. 196 p. (In Russian).

3. Zweifel H., Meyer R.D., Schiller M. Dobavki k polimeram: spravochnik [Additives to polymers: reference book]. Translated from English. $6^{\text {th }}$ ed. (Plastic Additives Handbook). Ed. by V.B. Uzdensky, A.O. Grigorova. Pro-Inform, 2010. 1144 p. (In Russian).

4. Kabanov V.A. Encyclopedia of polymers: Vol.2. / V.A. Kabanov and others. Moscow, Soviet encyclopedia, 1974. 1023 p. (In Russian)

5. Maslova I.P. Himicheskie dobavki k polimeram: spravochnik [Chemical additives to polymers: reference book]. Moscow, Himija [Chemistry], 1981. 264 p. (In Russian).

6. Kozlov P.V., Popkov S.P. Fiziko-himicheskie osnovy plastifikacii polimerov [Physico-chemical basis of plasticization of polymers]. Moscow, Himija [Chemistry], 1982. 224 p. (In Russian).

7. Verizhnikiv M.L. Razrabotka plastifikatorov PVH na osnove ciklicheskih formalej: dis. ... kand. him. nauk. [Development of PVC plasticizers on the base of cyclic formals: Ph.D. thesis]. Kazan, 2001. 104 p. (In Russian).

8. Oshin L.A. Promyshlennye hlororganicheskie produkty [Industrial chloroorganic products]. Moscow, Himija [Chemistry], 1978. 592 p. (In Russian).

9. Braginskiy O.B. Syr'evaja baza neftehimii: sovremennoe sostojanie i perspektivy razvitija [Raw-material base of petroleum chemistry: the current state and devel- 
opment prospects]. Materialy seminara «Hlororganicheskij sintez, tendencii rynka i tehnologij» [Materials of the workshop «Chlorooorganic synthesis, trends of market and technologies». Moscow, Publish. Moscow state academy of fine chemical technologies named after M.V. Lomonosov]. 2006. p. 4. (In Russian).

10. Mazitova A.K., Aminova G.K., Nafikova R.F., Deberdeev R.Ya. Osnovnye polivinilhloridnye kompozicii stroitel'nogo naznachenija [Main polyvinylchloride compositions for building purposes]. Ufa, 2013. 130 p. (In Russian).

11. Lazareva V.A., Kuchugurniy V.E., Bortnikova E.A. Plastifikatory: marketingovyj obzor [Plasticizers: marketing overview/ GP «CherkasskiyNIITEHIM»]. Cherkassy, 2011. 478 p. (In Russian).

12. Regulation (EC) №1907/2006 of the European Parliament and of the council of 18 December 2006 // Official Journal of the European Union. - 2007. - P. 146: [Electronic source]. URL:http://eur-lex.europa.eu/oj/2006/12/direct-access. html?ojYear=2016 (Accessed date: 09.11.2016).

13. Life Cycle Assessment of PVC and of principal competing materials, Commissioned by the European Commission: Final Report. - 2004. - 325 p.: [Electronic source]. URL:http://ec.europa. eu/enterprise/sectors/chemicals/ files/sustdev/pvc-final_report_lca_en.pdf (Accessed date: 09.11.2016).

14. Evaluation of new scientific evidence concerning DINP and DIDP in relation to entry 52 of Annex XVII to Regulation (EC) №1907/2006 (REACH): Draft Review Report. - 2012. - Version 3. - 312 p.: [Electronic source]. URL: http://echa.europa. eu/documents/10162/13641/echa_review_dinp_and_didp_en.pdf (Accessed date: 09.11.2016).

15. 1,2-Benzenedicarboxylic acid, di-C8-10-branched alkyl esters, C9-rich and di«isononyl» phthalate (DINP): European Union Risk Assessment Report / European Commission - Joint Research Centre, Institute for Health and Consumer Protection, European Chemicals Bureau (ECB). - Luxembourg: Office for Official Publications of the European Communities. - 2003. - Volume 35. - 288 p.: [Electronic source]. URL: http://echa.europa.eu/ documents/10162/8fa0a07f-ec2a4da6-bbe8-5b5e071b5c16 (Accessed date: 09.11.2016).

16. 1,2-Benzenedicarboxylic acid, di-C8-10-branched alkyl esters, C9-rich and di«isononyl» phthalate: Summary Risk Assessment Report / European Commission - Joint Research Centre, Institute for Health and Consumer Protection, European Chemicals Bureau (ECB). - 2003. - 19 p.: [Electronic source]. URL: http: // echa.europa.eu / documents/10162/0645f0cb-7880-4d23-acea-27b05ed7de39 (Accessed date: 09.11.2016).

17. 1,2-Benzenedicarboxylic acid, di-C9-11-branched alkyl esters, C10-rich and di«isodecyl»phthalate: European Union Risk Assessment Report / European Commission - Joint Research Centre, Institute for Health and Consumer Protection, European Chemicals Bureau (ECB). - Luxembourg: Office for Official Publications of the European Communities. - 2003. - Volume 36. - 222 p.: [Electronic source]. 
URL: http://www.didpfacts. com/upload/documents/document5.pdf (Accessed date: 09.11 .2016$)$.

18. 1,2-Benzenedicarboxylic acid, di-C9-11-branched alkyl esters, C10-rich and di«isodecyl» phthalate: Summary Risk Assessment Report / European Commission Joint Research Centre, Institute for Health and Consumer Protection, European Chemicals Bureau (ECB). - 2003. - 19 p.: [Electronic source]. URL:http://echa. europa.eu/documents/10162/b66cca3a-5303-455b-8355-3bf741e263b (Accessed date: 09.11.2016).

19. Mazitova A.K., Aminova G.K., Gabitov A.I., Maskova, A.R., Rakhmatullina R.G. Novye plastifikatory PVH-kompozicij special'nogo naznachenija [New plasticizers for PVC composites, special purpose]. Bashkirskij himicheskij zhurnal [Bashkir chemical journal]. 2015. Vol. 22, No. 3.pp. 23-26. (In Russian).

20. Mazitova A.K., Aminova G.K., Maskova A.R., Builova E.A., Nedopekin D.V. Difenoksijetilftalaty i butoksijetilfenoksijetilftalaty - novye plastifikatory polivinilhlorida [Diphenoxylate and butoxyethoxyethanol - new plasticizers of polyvinyl chloride]. Jelektronnyj nauchnyj zhurnal Neftegazovoe delo [Electronic scientific journal Oil and gas business]. 2015. No. 5. pp. 376-397. (In Russian).

21. Maskova A.R., Builova E.A., Aznabaev S.T., Mazitova A.K. O nekotoryh svojstvah butoksijetilbenzoksijetilftalatov [About some properties of butoxyethylbenzoxyethyl phthalates]. Promyshlennoe proizvodstvo i ispol'zovanie jelastomerov [Industrial production and use elastomers]. 2015. № 4. pp. 20-22. (In Russian).

22. Mazitova A.K., Stepanova L.B., Aminova G.K., Maskova A.R. Development of functional additives for polyvinyl chloride compositions of building purpose // Industrial production and use elastomers. - 2015. - № 2. - P. 27-31. (In Russian).

23. Mazitova A.K., Aminova G.K., Maskova A.R., Builova E.A. Novye ftalatnye plastifikatory dlja polivinilhloridnogo linoleuma [New phthalate plasticizers for PVClinoleum]. Neftegazovoe delo [Oil and gas business]. 2015. Vol. 13, № 3. pp. 83-86. (In Russian).

24. Mazitova A.K., Nafikova R.F., Aminova G.K., Gabitov A. I., Maskova A.R., Khusnutdinov B.R. Polivinilhloridnye kompozicii izoljacionnogo naznachenija na osnove ftalatov oksialkilirovannyh spirtov [Polyvinylchloride compositions for insulation purpose on the base of phthalates of oxyalkylated alcohol]. Promyshlennoe proizvodstvo i ispol'zovanie jelastomerov [Industrial production and use elastomers]. 2014. № 2. pp. 36-39. (In Russian).

25. Mazitova A.K., Aminova G.K., Gabitov A. I., Maskova A.R., Khusnutdinov B.R., Fattakhov A.M. Razrabotka novyh plastifikatorov polivinilhlorida [Development of new polyvinylchloride plasticizers]. Neftegazovoe delo [Oil and gas business]. 2014. № 12-1. pp. 120-127. (In Russian).

26. Aminova G.F., Gabitov A. I., Maskova A.R., Rysaev D.U., Goryushinskiy I.V. Novye tipy kompozicionnyh PVH-materialov otdelochnogo naznachenija [New types of 
composite PVC-materials for finishing purpose]. Proceedings of Kazan state university of architecture and engineering. 2013. № 3 (25). pp. 80-85. (In Russian).

27. Aminova G.F., Gabitov A.I., Maskova A.R., Khusnutdinov B.R., Abdrakhmanova L.K., Nafikova R.F. Producing of linoleum with improved physical and mechanical properties. Jelektronnyj nauchnyj zhurnal Neftegazovoe delo [Electronic scientific journal «Oil and gas business»]. 2013. № 6. pp. 508-537.

28. Maskova A.R., Stepanova L.B., Aminova G.K. Ispytanie receptur PVH-materialov stroitel'nogo naznachenija $\mathrm{s}$ ispol'zovaniem simmetrichnyh i nesimmetrichnyh ftalatov oksialkilirovannyh spirtov [Tests of formulations of PVC-materials for construction purpose with the use of symmetric and unsymmetric phthalates of oxyalkylated alcohol]. Proceedings of Kazan state university of architecture and engineering. 2012. № 2. pp. 177-182. (In Russian).

29. Aminova G.K., Nafikova R.F., Maskova A.R., Mazitova A.K. Polivinilhloridnye linoleumy: monografija [Polyvinylchloride linoleum: monograph]. kn. Nauka i jepoha [In the book: Science and epoch]. Aminova G.K., Bagnetova E.A., Barsukova S.A., Beznebeeva A.M., Gersh K.V., Eremin V.N., Kaveeva I.A., Kachugina T.V., Mazitova A.K., Maskova A.R., Mootorina S.V., Nafikova R.F., Ponomareva T.I., Yashkova A.N. Voronezh state pedagogical university. Moscow- Voronezh, 2013, pp. 187-212. (In Russian).

30. Aminova G.F., Gabitov A.I., Maskova A.R., Yagafarova G.G., Rolnik L.Z., Klyavlin M.S. New composite PVC-material for finishing purposes, plasticized by butoxyalkylphenoxyalkyl phthalates // Jelektronnyj nauchnyj zhurnal Neftegazovoe delo [Electronic scientific journal «Oil and gas business»]. 2013, № 5, pp. 353-362. (In Russian).

31. Aminova G.F., Maskova A.R., Nafikova R.F., Gorelov V.S., Abdrakhmanova L.K., Mazitova A.K. Issledovanie fiziko-mehanicheskih pokazatelej polivinilhloridnyh kompozicij [Investigation of physical and mechanical characteristics of polyvinylchloride compositions]. Promyshlennoe proizvodstvo i ispol'zovanie jelastomerov [Industrial production and use elastomers]. 2013, № 2, pp. 40-46. (In Russian).

\section{DeAR COlleagues!}

THE REFERENCE TO THIS PAPER HAS THE FOLLOWING CITATION FORMAT:

Mazitova A.K., Aminova G.K., Maskova A.R., Yagafarova G.G., Mazitov R.M. New plasticizers for PVC-compositions in construction. Nanotehnologii v stroitel'stve = Nanotechnologies in Construction. 2017, Vol. 9, no. 4, pp. 48-63. DOI: dx.doi. org/10.15828/2075-8545-2017-9-4-48-63. 
Автор: МАЗИТОВА Алия Карамовна, д.х.н., профессор, зав. каф. «Прикладные и естественнонаучные дисциплины», ФГБОУ ВО «Уфимский государственный нефтяной технический университет»; ул. Менделеева, 195, г. Уфа, Республика Башкортостан, Россия, 450080, elenaasf@yandex.ru;

Автор: АМИНОВА Гулия Карамовна, д.т.н., проф. каф. «Прикладные и естественнонаучные дисциплины», ФГБОУ ВО «Уфимский государственный нефтяной технический университет»; ул. Менделеева, 195, г. Уфа, Республика Башкортостан, Россия, 450080, aminovagk@inbox.ru;

Автор: МАСКОВА Альбина Рафитовна, к.т.н., доцент каф. «Прикладные и естественнонаучные дисциплины», ФГБОУ ВО «Уфимский государственный нефтяной технический университет»; ул. Менделеева, 195, г. Уфа, Республика Башкортостан, Россия, 450080, asunasf@mail.ru; Автор: ЯГАФАРОВА Гузель Габдулловна, д.т.н., проф., зав. каф. «Прикладная экология», ФГБОУ ВО «Уфимский государственный нефтяной технический университет»; ул. Космонавтов, 1 , г. Уфа, Республика Башкортостан, Россия, 450062, Kafedra_ecologia@mail.ru;

Автор: МАЗИТОВ Руслан Мидхатович, к.т.н., доцент, доцент каф. «История и политология», ФГБОУ ВО «Уфимский государственный нефтяной технический университет»; ул. Космонавтов, 1 , г. Уфа, Республика Башкортостан, Россия, 450062, mazitovps@mail.ru

\section{НОВЫЕ ПЛАСТИФИКАТОРЫ ДЛЯ ПВХ-КОМПОЗИЦИЙ СТРОИТЕЛЬНОГО НАЗНАЧЕНИЯ}

АННОТАЦИЯ К СТАТЬЕ (АВТОРСКОЕ РЕЗЮМЕ, РЕФЕРАТ):

Работа посвящена анализу и разработке эффективных видов пластификаторов для широкой номенклатуры отделочных (линолеум) и изоляционных строительных материалов (изоляционная лента, кабельный пластикат) с улучшенными механическими и техническими характеристиками. В связи с ростом объемов потребления отделочных и изоляционных материалов, разработка новых рецептур ПВХ-композиций строительного назначения с применением новых пластификаторов является не только актуальной задачей, но и в рамках строительства позволяет решать задачи эффективного управления качеством готовой поливинилхлоридной композиции.

В работе приведены результаты испытаний октилфеноксиэтилфталатов в качестве новых химикатов-добавок при пластификации ПВХ в рецептурах верхнего и промежуточного слоев линолеума, ленты липкой, а также кабельного пластиката 0-40 рец. 0M-40 (черный). Отмечено, что полученные образцы ленты липкой по своим основным показателям - прочность при разрыве, относительное удлинение, температура хрупкости, термостабильность - со- 
ответствуют ТУ 2245-001-00203312-2003. Полученные образцы пластиката, анализированные согласно ГОСТ 5960-72 с изм. 1-9 (Пластикат поливинилхлоридный для изоляции и защитных оболочек проводов и кабелей), по основным показателям - удельное объемное электрическое сопротивление, прочность при разрыве, относительное удлинение при разрыве, температура хрупкости - не уступают промышленным образцам, а такие показатели как «Потери в массе при $160^{\circ} \mathrm{C}$ и «Водопоглощение» значительно ниже. Отмечено, что при использовании октилфеноксиэтилфталатов полученные образцы пленок верхнего и промежуточного слоев линолеума, анализированные согласно СТП 00203312-100-2006, обладают более высокими значениями текучести расплава. $К$ тому же пленки, полученные с введением в рецептуру предложенных нами пластификаторов, обладают низкими значениями экстрагируемости бензином и маслами.

Ключевые слова: бензостойкость, водопоглощение, лента ПВХ липкая, маслостойкость, материалы для изоляции проводов и кабелей, октилфеноксиэтилфталаты, пластификаторы поливинилхлорида, слой линолеума, твердость по Шору, термостабильность.

DOI: dx.doi.org/10.15828/2075-8545-2017-9-4-48-63

МАШИНОЧИТАЕМАЯ ИНФОРМАЦИЯ о СС-ЛИЦЕНЗИИ в МЕТАДАННЫХ СТАТЬИ (HTML-КОД):

$<$ a rel="license" href="http://creativecommons.org/licenses/by/4.0/" ><img alt="Лицензия Creative Commons" style="borderwidth:0" src="https://i.creativecommons.org/l/by/4.0/88x31.png" / $></ \mathrm{a}><$ br $/>$ Произведение «<span xmlns:dct="http:// purl.org/dc/terms/" href="http://purl.org/dc/dcmitype/Text" property="dct:title" rel="dct:type">Новые пластификаторы для пвх-композиций строительного назначения </span>» созданное автором по имени <a xmlns:cc="http://creativecommons. org/ns\#" href="Нанотехнологии в строительстве. - 2017. - Toм 9, № 4. - C. 48-63. - DOI: dx.doi.org/10.15828/2075-85452017-9-4-48-63." property="cc:attributionName" rel="cc:attributionURL"> Мазитова А.К., Аминова Г.К., Маскова А.Р., Ягафарова Г. Г., Мазитов Р.М. </a $>$, публикуется на условиях $<$ a rel="license" href="http://creativecommons.org/licenses/ by/4.0/">лицензии Creative Commons «Attribution» ( «Атрибуция») 4.0 Всемирная $</ \mathrm{a}>$. $<\mathrm{br} />$ Основано на произведении c $<$ a xmlns:dct="http://purl.org/dc/terms/" href="http://nanobuild.ru/ru_RU/nanobuild-4-2017/" rel="dct:source">http:// nanobuild.ru/ru_RU/nanobuild-4-2017/</a>.<br />Разрешения, выходящие за рамки данной лицензии, могут быть доступны на странице $<$ a xmlns:cc="http://creativecommons.org/ns\#" href="elenaasf@yandex.ru" rel="cc:morePermissions">elenaa $\mathrm{sf@yandex.ru</a>}$.

\section{Библиографический список:}

1. Тиниус К. Пластификаторы. - М.: Химия, 1964. - 915 с.

2. Барштейн Р.С., Кириллович В.И., Носовский Ю.Е. Пластификаторы для полимеров. - М.: Химия, 1982. - 196 с.

3. Цвайфель X., Маер Р.Д., Шиллер М. Добавки к полимерам: справочник. пер. с англ. 6-го изд. (Plastic Additives Handbook), под. ред. В.Б. Узденского, А.О. Григорова. - Профи-Информ, 2010. - 1144 с. 
4. Кабанов В.А. Энциклопедия полимеров. - М.: Советская энциклопедия, 1974. T. 2. $-1023 \mathrm{c}$.

5. Маслова И.П. Химические добавки к полимерам: справочник. - М.: Химия, 1981. $-264 \mathrm{c}$.

6. Козлов П.В., Попков С.П. Физико-химические основы пластификации полимеров. -М.: Химия, 1982. -224 с.

7. Верижников М.Л. Разработка пластификаторов ПВХ на основе циклических формалей: дис. ... канд. хим. наук. - Казань, 2001. - 104 с.

8. Ошин Л.А. Промышленные хлорорганические продукты. - М.: Химия, 1978. 592 c.

9. Брагинский О.Б. Сырьевая база нефтехимии: современное состояние и перспективы развития // Материалы семинара «Хлорорганический синтез, тенденции рынка и технологий». - М.: Изд. Московской государственной академии тонкой химической технологии имени М.В. Ломоносова, 2006. - С. 4.

10. Мазитова А.К., Алинова Г.К., Нафикова Р.Ф., Дебердеев Р.Я. Основные поливинилхлоридные композиции строительного назначения. - Уфа, 2013. - 130 с.

11. Лазарева В.А., Кучугурный В.Е., Бортникова Е.А. Пластификаторы: маркетинговый обзор // ГП «ЧеркасскийНИИТЭХИМ». - Черкассы, 2011. - 478 с.

12. Regulation (EC) № $1907 / 2006$ of the European Parliament and of the council of 18 December 2006 // Official Journal of the European Union. - 2007. - P. 146. [Электронный pecypc]. - URL:http://eur-lex.europa.eu/oj/2006/12/directaccess.html?ojYear=2016 (Дата обращения: 09.11.2016).

13. Life Cycle Assessment of PVC and of principal competing materials, Commissioned by the European Commission: Final Report. - 2004. - 325 р.: [Электронный реcypc]. URL:http://ec.europa. eu/enterprise/sectors/chemicals/ files/sustdev/ pvc-final_report_lca_en.pdf (Дата обращения: 09.11.2016).

14. Evaluation of new scientific evidence concerning DINP and DIDP in relation to entry 52 of Annex XVII to Regulation (EC) №1907/2006 (REACH): Draft Review Report. - 2012. - Version 3. - 312 p.: [Электронный pecypc]. URL: http://echa. europa.eu/documents/10162/13641/echa_review_dinp_and_didp_en.pdf (Дата обращения: 09.11.2016).

15. 1,2-Benzenedicarboxylic acid, di-C8-10-branched alkyl esters, C9-rich and di-«isononyl» phthalate (DINP): European Union Risk Assessment Report / European Commission - Joint Research Centre, Institute for Health and Consumer Protection, European Chemicals Bureau (ECB). - Luxembourg: Office for Official Publications of the European Communities. - 2003. - Volume 35. - 288 р.: [Электронный ресурс]. URL: http://echa.europa.eu/ documents/10162/8fa0a07fec2a-4da6-bbe8-5b5e071b5c16 (Дата обращения: 09.11.2016).

16. 1,2-Benzenedicarboxylic acid, di-C8-10-branched alkyl esters, C9-rich and di«isononyl» phthalate: Summary Risk Assessment Report / European Commission Joint Research Centre, Institute for Health and Consumer Protection, European Chemicals Bureau (ECB). - 2003. - 19 р.: [Электронный pecypc]. URL:http : // 
echa.europa.eu / documents/10162/0645f0cb-7880-4d23-acea-27b05ed7de39 (Дата обращения: 09.11.2016).

17. 1,2-Benzenedicarboxylic acid, di-C9-11-branched alkyl esters, C10-rich and di-«isodecyl» phthalate: European Union Risk Assessment Report / European Commission - Joint Research Centre, Institute for Health and Consumer Protection, European Chemicals Bureau (ECB). - Luxembourg: Office for Official Publications of the European Communities. - 2003. - Volume 36. - 222 p.: [Электронный ресурс]. URL: http://www.didpfacts. com/upload/documents/ document5.pdf (Дата обращения: 09.11.2016).

18. 1,2-Benzenedicarboxylic acid, di-C9-11-branched alkyl esters, C10-rich and di«isodecyl» phthalate: Summary Risk Assessment Report / European Commission Joint Research Centre, Institute for Health and Consumer Protection, European Chemicals Bureau (ECB). - 2003. - 19 p.: [Электронный pecypc]. URL:http:// echa.europa.eu/documents/10162/b66cca3a-5303-455b-8355-3bf741e263b (Дата обращения: 09.11.2016).

19. Мазитова А.К., Алинова Г.К., Габитов А.И., Маскова А.Р., Рахлатуллина Р.Г. Новые пластификаторы ПВХ-композиций специального назначения // Башкирский химический журнал. - 2015. - Т. 22, № 3. - С. 23-26.

20. Мазитова А.К., Алинова Г.К., Маскова А.Р., Буйлова Е.А., Недопекин Д.В. Дифеноксиэтилфталаты и бутоксиэтилфеноксиэтилфталаты - новые пластификаторы поливинилхлорида // Электронный научный журнал Нефтегазовое дело. - 2015. - № 5. - С. 376-397.

21. Маскова А.Р., Буйлова Е.А., Азнабаев Ш.T., Мазитова А.К. О некоторых свойствах бутоксиэтилбензоксиэтилфталатов // Промышленное производство и использование эластомеров. - 2015. - № 4. - С. 20-22.

22. Мазитова А.К., Степанова Л.Б., Алинова Г.Ф., Маскова А.Р. Разработка функциональных добавок для поливинилхлоридных композиций строительного назначения // Промышленное производство и использование эластомеров. 2015. - № 2. - С. 27-31.

23. Мазитова А.К., Алинова Г.К., Маскова А.Р., Буйлова Е.А. Новые фталатные пластификаторы для поливинилхлоридного линолеума // Нефтегазовое дело. - 2015. - Т. 13, № 3. - С. 83-86.

24. Мазитова А.К., Нафикова Р.Ф., Алинова Г.Ф., Габитов А.И., Маскова А.Р.,

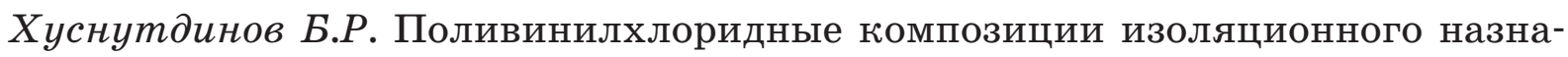
чения на основе фталатов оксиалкилированных спиртов // Промышленное производство и использование эластомеров. - 2014. - № 2. - С. 36-39.

25. Мазитова А.К., Алинова Г.Ф., Габитов А.И., Маскова А.Р., Хуснутдинов Б.Р., Фаттахова A.M. Разработка новых пластификаторов поливинилхлорида // Нефтегазовое дело. - 2014. - № 12-1. - С. 120-127.

26. Алинова Г.Ф., Габитов А.И., Маскова А.Р., Рысаев Д.У., Горюшинский И.В. Новые типы композиционных ПВХ-материалов отделочного назначения // Из- 
вестия Казанского государственного архитектурно-строительного университета. - 2013. - № 3 (25) . - С. 80-85.

27. AminovaG.F.,Gabitov A.I.,MaskovaA.R., Khusnutdinov B.R.,Abdrakhmanova L.K., Nafikova R.F. Producing of linoleum with improved physical and mechanical properties // Нефтегазовое дело. - 2013. - № 6. - С. 508-537.

28. Маскова А.Р., Степанова Л.Б., Алинова Г.К. Испытание рецептур ПВХматериалов строительного назначения с использованием симметричных и несимметричных фталатов оксиалкилированных спиртов / / Известия Казанского государственного архитектурно-строительного университета. - 2012. - № 2. С. 177-182.

29. Алинова Г.К., Нафикова Р.Ф., Маскова А.Р., Мазитова А.К. Поливинилхлоридные линолеумы: монография // кн. Наука и эпоха. - Воронежский государственный педагогический университет. - Москва-Воронеж, 2013. - С. 187-212.

30. Aminova G.F., Gabitov A.I., Maskova A.R., Yagafarova G.G., Rolnik L.Z., Klyavlin M.S. New composite PVC-material for finishing purposes, plasticized by butoxyalkylphenoxyalkyl phthalates // Нефтегазовое дело. - 2013. - № 5. C. 353-362.

31. Алинова Г.К., Маскова А.Р., Нафикова Р.Ф., Горелов В.С., Абдрахланова Л.К., Мазитова А.К. Исследование физико-механических показателей поливинилхлоридных композиций // Промышленное производство и использование эластомеров. - 2013. - № 2. - С. 40-46.

\section{УВАЖАЕМЫЕ КОЛЛЕГИ!}

ПРИ ИСПОЛЬЗОВАНИИ МАТЕРИАЛА ДАННОЙ СТАТЬИ

ПРОСИМ ДЕЛАТЬ БИБЛИОГРАФИЧЕСКУЮ ССЫЛКУ НА НЕЁ:

Мазитова А.К., Алинова Г.К., Маскова А.Р., Ягафарова Г. Г., Мазитов Р.М. Новые пластификаторы для пвх-композиций строительного назначения // Нанотехнологии в строительстве. - 2017. - Том 9, № 4. - C. 48-63. - DOI: dx.doi. org/10.15828/2075-8545-2017-9-4-48-63.

\section{DeAr COLLEAGUES!}

THE REFERENCE TO THIS PAPER HAS THE FOLLOWING CITATION FORMAT:

Mazitova A.K., Aminova G.K., Maskova A.R., Yagafarova G.G., Mazitov R.M. New plasticizers for PVC-compositions in construction. Nanotehnologii v stroitel'stve= Nanotechnologies in Construction. 2017, Vol. 9, no. 4, pp. 48-63. DOI: dx.doi. org/10.15828/2075-8545-2017-9-4-48-63. 